\title{
Review of Gandhi's Ascetic Activism: Renunciation and Social Action by Veena R. Howard
}

\author{
Brenda Llewellyn Ihssen
}

\author{
Correspondence: ihssenbl@plu.edu \\ Pacific Lutheran University, Tacoma, \\ Washington, USA
}

\author{
Book details \\ Veena R. Howard. \\ Gandhi's Ascetic Activism: Renunciation and Social Action. \\ State University of New York Press, 2013. 314 pages. ISBN 978-1438445564.
}

Keywords: Activism; Asceticism; Brahmacarya; Celibacy; Gandhi; India; Sadhu

Following a line of research inquiry that challenges academic assumptions regarding Gandhi's asceticism, Veena R. Howard's Gandhi's Ascetic Activism: Renunciation and Social Action introduces scholars and interested lay readers to a new way of thinking about the provocative austerity (tapas) practices and ascetic philosophy of Mohandas Gandhi. A particularly engaging Introduction (1-19) introduces the reader to the trajectory of her study, including an explanation of the central paradox, key questions and methodology. Beyond this, each of Howard's chapters unpacks exceptional and identifiable elements of Gandhi's austerities and the distinctiveness of their intended outcome; at the same time, she traces an articulate chronicle of cultural, political and literary factors that influenced and tested the preeminent founder of the non-violent component of the Indian Independence Movement. Central to Howard's analysis is her claim that Gandhi's asceticism challenged conventional components of Indic ascetic practices and this challenge was embraced due to Gandhi's fundamental belief that the primary task of the holy man $(s \bar{a} d h u)$ was social engagement through ascetic activity for the purpose of political improvement (30).

While Chapters One, Three and Five provide exploration and analysis of Gandhi's synthesis of ascetic and political activism, the traditional roots of his celibacy (brahmacarya) and his creative interplay with Indic ascetic legends and heroes respectively, especially noteworthy are Chapters Two and Four, each of which operates both as a masterful analysis of Howard's over-arching central argument and as a stand-alone piece for those seeking the heart and soul of Howard's significant contribution. Howard masterfully traces the transformational process by which Gandhi developed and arrived at a theoretical framework that would support "a living strategy," (41) one which would successfully graft the sovereign Indic value of renunciation from the wilderness to the village. Howard's vast knowledge of and facility with Gandhi's voluminous writings-as well as those that influenced him-allows the reader to engage intimately in Gandhi's struggle to

(c) 2015 Llewellyn Ihssen. Open Access This article is distributed under the terms of the Creative Commons Attribution 4.0 International License (http://creativecommons.org/licenses/by/4.0/), which permits unrestricted use, distribution, and reproduction in any medium, provided you give appropriate credit to the original author(s) and the source, provide a link to the Creative Commons license, and indicate if changes were made. 
call into service those who believed that the ritual activities of the religious realm had no business placing themselves at the service of society. In fact, Howard notes in a later chapter, despite clear management of brahmacarya among students of divine conduct, such a one-dimensional view of the celibate life distorts the importance of the variations and nuances of celibacy observed in secular Hindu society, among married and non-married, men and women, for different durations and variety of purpose (89).

Chapter Four, "Gandhi's Unorthodox Brahmacarya: Reinterpreting Private Religious Practice for Public Service," is concerned only partially with the extensive curiosity around Gandhi's provocative, public brahmacarya rituals. Of greater concern for Howard is that this most intimate of ascetic religious rituals was, for Gandhi, never an intimate issue. Rather, she argues, in a fashion quite distinct from other sädhus Gandhi openly contravened regulations of sexual renunciation as a means to achieving his primary goal for India of self-rule (svaräj), which, for Gandhi, encompassed the political, religious and the sexual realms (152). Howard highlights in this chapter his particular concern to address the social injustices of women and the oppression they faced, and he encouraged and counseled for brahmacarya as the solution. It is worth noting that despite a laudatory treatment of Gandhi in this chapter, Howard does not shy from identifying that not all scholars appreciate Gandhi's approach towards female autonomy in equal measure (160).

Those who engage in rituals of extreme abstinence are by nature provocative in their renunciation and, sometimes, denunciation of customary features of life (even if their social relations with each other and with society suggest otherwise). Gandhi, on the other hand, engaged in renunciation practices-Howard argues-precisely for and in defense of a world he believed was simultaneously transformable and transformative. Subsequent conflation of particular Indic ascetic ideals with Gandhi's love of humanity, validation of the human body and spirit and-perhaps most defiantly-his application of austerity for socio-political goals such as the overthrow of oppressive political structures and repressive social customs set him apart from ascetic and non-ascetic contemporaries, both of whom viewed his methods and motives with deep suspicion. This placed Gandhi in a category apart from contemporaries who believed that principles of the householder and principles of the renouncer should be polarized, even if the boundaries were not necessarily so (25). Howard's sharp analysis of Gandhi's creative vision reminds us that the business of social transformation is rarely found in a tidy, immaculate approach.

Competing interests

The author declares that she has no competing interests.

Received: 21 March 2015 Accepted: 6 August 2015

Published online: 13 August 2015 